\title{
The Performance of Decentralisation Strategies Compared: An Assessment of Decentralisation Strategies and their Impact on Local Government Performance in Germany, France and England
}

\author{
FALK EBINGER*, STEPHAN GROHS** \& RENATE REITER*** \\ *Ruhr University, Bochum, Germany, **University of Konstanz, Germany, \\ ***Fern University, Hagen, Germany
}

\begin{abstract}
The aim of this paper is to evaluate the impact of differing decentralisa tion strategies political, administrative and horizontal on administrative performance subsequent to reform. In this respect, the paper presents core results from a comprehensive research project that has been carried out between 2006 and 2009 on the impact of decentralisation in three European countries. The aim of the project has been to develop and apply an analytical framework for the measurement of the effects of national decentralisation policies on local government performance. A total of six reform ventures were scrutinised in French, German and English local communities applying a multidimensional set of performance measures. Surprisingly, many of the theoretical assumptions about the effects of decentralisation strategies could not be confirmed. Moreover, straightforward relations were not discovered between decen tralisation strategies and performance effects but between policy fields, political interests and the time elapsed since the reform and performance.
\end{abstract}

KEY WORDS: Decentralisation, public administration, performance measurement, multilevel governance, local government

\section{Introduction}

One of the most prominent discussions in local government and administration research is about where and how competencies should be allocated in the 'ideal' administrative setup. In the context of rising fiscal pressures,

Correspondence Address: Falk Ebinger MA, Ruhr Universitat Bochum Fakultat fur Sozialwis senschaft. E mail: Falk.Ebinger@ruhr uni bochum.de 
central governments' faltering ambitions to control all spheres of live and a local government level thriving for comprehensive responsibility, more diverse and complex solutions were embraced all over Europe (Pollitt \& Bouckaert, 2004; Pollitt, 2005; Denters \& Rose, 2005; Deffigier, 2007; Ahmad $\&$ Brosio, 2008). Local government seems to be caught in ceaseless change, driven by political power games (Bogumil \& Ebinger, 2008). Between the ideal types of comprehensive local responsibility and the preponderance of state agencies in public service delivery, all kinds of hybrids and divisions of labour can be identified. Hypotheses on the performance of certain institutional configurations are galore in research and among practitioners. Empirical evidence is weak though and comparative evaluations of different institutional setups are hard to find. This article aims to step into this gap by analysing the effects observed in the aftermath of decentralisation. To do so, a comprehensive analytical framework is applied to three prominent decentralisation strategies - political decentralisation, administrative decentralisation and deconcentration. The goal is to review widespread assumptions on the effects of differing divisions of labour between the state and local level and to identify underlying causal relations. These strategies have been analysed by the authors in six reform ventures in selected policy fields in Germany, France and England. The studies formed the empirical core of a comprehensive research project on the impact of national decentralisation policies on local government performance in the three countries. In this article we deliver a concentrated and inevitably only partial picture of the empirical results. ${ }^{1}$ The article proceeds as follows: after outlining the popular hypotheses on decentralisation effects and the ideal-type models of decentralisation, a sixdimensional model of the potential impact of decentralisation is developed on a theoretical basis. In a third step, the empirically observed change in each of the performance dimensions is presented for the three decentralisation strategies.

\section{Hypotheses and models of decentralisation}

Our argument is based on the premise that the performance of local government is a function of the specific organisational model in public administration and the intergovernmental setting in the respective state (Pollitt/Bouckaert, 2004; Wollmann/Bouckaert, 2006). We therefore assume that a shift in the organisation of public administration and the intergovernmental setting as instigated by national decentralisation reforms should lead to a change in local governments' performance. We furthermore assume that the characteristics of this change depend on the decentralisation strategy chosen.

Departing from Wollmann's classification of public administrative organisation, two ideal-type institutional setups can be distinguished: the multi-purpose model and the single-purpose model of local government and administration. In the first case local governments are responsible for most or all public functions within a given, territorially defined jurisdiction. In the 
second case different types of administrative bodies are charged with only one main purpose and responsibility is horizontally and vertically fragmented between departments and levels of government (Wollmann/ Bouckaert, 2006: 12-14; Wollmann, 2004). All decentralisation strategies can be located in between these two poles.

Following the literature on state and local government reform, three typical decentralisation strategies can be identified (Benz, 2002: 209-214; Wollmann, 2004): the first form, political decentralisation, can be defined as the transfer of state functions that have either been located previously on the level of central government itself or on states' decentral agencies into the sphere of local government. Political decentralisation means that locally legitimised bodies become competent to decide autonomously on the planning, financing and administration of their newly acquired executive functions. Compared to this rather far-reaching step, administrative decentralisation marks a more moderate form of reordering of intergovernmental relations. It is defined as the concession of executive functions from the state to local administrative authorities without the assignment of locally elected bodies to decide autonomously on the purpose. Acting as agents of national governments or governmental offices local authorities remain at least formally under the states' full control, not only of the legality but also of the functionality and the professional quality of the respective action (Wollmann, 1997: 106). Finally, administrative deconcentration is defined as the delegation of central state functions to administrative bodies located on the sub-central level of government. These affected bodies are not local governments but are still part of the states' own administration or are dependent on the state e.g. regarding organisation or financing. Yet, as they assume delegated functions they do not act under direct state control but are granted varying degrees of autonomy. Subsumed are the 'classic' delegation of central state functions to governmental bodies as government agencies and the assignment of functions to quangos (quasinon-governmental-organisations, Skelcher, 1998). This kind of 'horizontal' decentralisation is typical for state restructuring in the Anglo-Saxon countries (Wilson \& Game, 2006). Here the state often keeps direct financial and juridical control of the decentralised fulfilment of tasks by quasiautonomous bodies.

We can presume differences in performance effects for each of the three decentralisation strategies that are shared widely in the relevant literature (cf. Pollitt, 2005). In the case of political decentralisation we can presume increasing democratic control and accountability, better horizontal coordination capacity and partly improved effectiveness due to problem orientation and responsiveness (Wagener, 1976; Wollmann, 1997, 2004, 2008). These virtues go hand in hand with the downside of decreasing vertical coordination, partly lower effectiveness (due to under-specialisation) and efficiency (due to decreasing economies of scale). Regarding the equity dimension we can presume growing heterogeneity between local governments (Bogumil/Reichard/Siebart, 2004; Bauer et al., 2007; 
Ebinger/Bogumil, 2008; Kuhlmann, 2006). For the case of administrative decentralisation we can expect a softening of the positive and negative effects compared to political decentralisation. While democratic control and accountability as well as horizontal coordination is assumed to improve only in limited ways, vertical coordination, effectiveness, efficiency and homogeneity of service delivery should maintain a higher level due to central support and standardisation. Administrative deconcentration finally can be read as the mere opposite of political decentralisation with decreasing democratic control and horizontal coordination, but improved vertical coordination, increasing efficiency and effectiveness due to specialisation. By reasons of similar capacities and procedural specifications we can expect higher equity.

\section{Methods}

How can the theoretically deduced assumptions about the effects of decentralisation strategies on local government performance be approached in empirical research? The evaluation of public sector reforms faces numerous methodological and conceptual difficulties. One problem is that the performance of public institutions is influenced by manifold intervening factors. Consequently, it is often not possible to clearly isolate the impact of institutional changes (cf. Pollitt \& Bouckaert, 2004: 103ff, Boyne et al., 2003: $13 \mathrm{ff}$.). Second, we cannot draw on an elaborated set of indicators to survey performance improvements, which is partly because the target dimensions of modernisation are only very generally formulated, often inconsistent and even contradictory (cf. Bogumil \& Kuhlmann, 2006) as well as changing over time. Following Pollitt and Bouckaert (2004: 6) administrative reforms usually serve multiple ends such as savings, improvement of quality, efficiency and effectiveness of the service or product delivery. Moreover intermediate ends as improvement of political steering capacity or administrative independence as well as pure symbolic benefits might be furthered. Furthermore, the evaluation and the weighting of individual dimensions vary depending on the perspective and institutional affiliation of various stakeholder groups (cf. Connolly et al., 1980; Boyne et al., 2003: 14; Enticott, 2004).

These conditions make it necessary to develop a multidimensional framework allowing for a comprehensive coverage of the constitutive dimensions of performance and which is oriented on the scientific discussion as well as apt to reflect the multiple perspectives on the issues dealt with. When presenting the assumed performance effects of the three decentralisation strategies above, we already briefly introduced a set of performance indicators. For the deduction of these performance dimensions we were geared to the distinction of the single- and multi-purpose models outlined above (cf. Wollmann, 2004; Benz, 2002) as well as to the discussion on performance indicators for NPM-style public sector-reforms 
(cf. Pollitt/Bouckaert, 2004: 103-142; Bogumil et al., 2007; Kuhlmann et al., 2008). We discern six distinct performance dimensions, which relate to three aspects of input legitimacy (democratic control and accountability, transparency), procedural aspects of coordination and steering, output legitimacy (efficiency and effectiveness of service delivery) and finally aspects of equity of service delivery between territorial units. To operationalise these performance dimensions, each is attributed with a set of measurable indicators, which are presented in Table 1. Even if there is not always a

Table 1. Dimensions and indicators for the measurement of local government performance

\begin{tabular}{|c|c|c|}
\hline $\begin{array}{l}\text { Performance } \\
\text { dimensions }\end{array}$ & Indicators & Meaning \\
\hline \multirow[t]{5}{*}{$\begin{array}{l}\text { Democratic } \\
\text { control and } \\
\text { accountability }\end{array}$} & $\begin{array}{l}\text { Formal gain in } \\
\text { political } \\
\text { competences }\end{array}$ & $\begin{array}{l}\text { Local councils gain in formal competences in } \\
\text { policy making and implementation leading to } \\
\text { a strengthening of local democracy? }\end{array}$ \\
\hline & $\begin{array}{l}\text { Factual gain in } \\
\text { political leeway }\end{array}$ & $\begin{array}{l}\text { Local councils gain in factual power in policy } \\
\text { making and implementation leading to a } \\
\text { strengthening of local democracy? }\end{array}$ \\
\hline & $\begin{array}{l}\text { Inclusion of } \\
\text { organised interests }\end{array}$ & $\begin{array}{l}\text { Integration of organised interests into local } \\
\text { decision making? }\end{array}$ \\
\hline & Inclusion of citizens & $\begin{array}{l}\text { Integration of citizens beyond delineated interest } \\
\text { groups? }\end{array}$ \\
\hline & Transparency & $\begin{array}{l}\text { Decision makers, responsibilities and rationales } \\
\text { transparent to the public? }\end{array}$ \\
\hline \multirow[t]{3}{*}{$\begin{array}{l}\text { Horizontal } \\
\text { coordination }\end{array}$} & $\begin{array}{l}\text { Coordination } \\
\text { requirements }\end{array}$ & $\begin{array}{l}\text { Fewer stakeholders, more congruent goals, } \\
\text { smaller cultural and/or spatial distance in } \\
\text { horizontal relations? }\end{array}$ \\
\hline & Conflict level & $\begin{array}{l}\text { Reduced frequency and intensity of disputes } \\
\text { between stakeholders? }\end{array}$ \\
\hline & Constructiveness & Success in coordination ventures? \\
\hline \multirow[t]{3}{*}{$\begin{array}{l}\text { Vertical } \\
\text { coordination }\end{array}$} & $\begin{array}{l}\text { Coordination } \\
\text { requirements }\end{array}$ & $\begin{array}{l}\text { Fewer stakeholders, more congruent goals, } \\
\text { smaller cultural and/or spatial distance in } \\
\text { horizontal relations? }\end{array}$ \\
\hline & Conflict level & $\begin{array}{l}\text { Reduced frequency and intensity of disputes } \\
\text { between stakeholders? }\end{array}$ \\
\hline & Constructiveness & Success in coordination ventures? \\
\hline \multirow[t]{4}{*}{ Efficiency } & Savings & Reduced amount of expended resources? \\
\hline & Input output ratio & Improved relation of in and outputs \\
\hline & Economies of scale & $\begin{array}{l}\text { Heightened output or reduced costs e.g. as a } \\
\text { result of division of labour, automatisation or } \\
\text { routinisation? }\end{array}$ \\
\hline & Economies of scope & $\begin{array}{l}\text { Synergies due to optimised use of resources } \\
\text { across bundles of related tasks? }\end{array}$ \\
\hline \multirow[t]{4}{*}{ Effectiveness } & Legal quality & $\begin{array}{l}\text { Formal correctness; use of discretionary space in } \\
\text { decision making? }\end{array}$ \\
\hline & Professional quality & $\begin{array}{l}\text { Resources (qualification, manpower, equipment, } \\
\text { independence) available and applied state of } \\
\text { the art? }\end{array}$ \\
\hline & $\begin{array}{l}\text { Customer } \\
\text { orientation }\end{array}$ & Improvement of local problem solving capacity? \\
\hline & Availability & $\begin{array}{l}\text { Improved opening hours and/or spatial } \\
\text { proximity to citizens? }\end{array}$ \\
\hline Equity & Inter local equality & $\begin{array}{l}\text { Analogue decisions and service fulfilment in an } \\
\text { inter communal perspective? }\end{array}$ \\
\hline
\end{tabular}


quantifiable measure behind these dimensions, it is possible to identify the direction of the development over time (before and after the reform) by the use of expert judgements and document analyses. To avoid biases by single perspectives we interviewed several stakeholder groups and could realise a rather reliable within-case control (cf. George \& Bennett 2005; Munck 2004). Where no distinct judgements were possible we report the differing perspectives.

In order to test the hypotheses on the effects of decentralisation strategies, we apply our model to six specific reform ventures in Germany, France and England. These three states started from diverging origins and deployed (seemingly randomly) different institutional policies to decentralisation and the rearrangement of central-local-relations over the past two decades (Kuhlmann, 2006). Four cases can be defined as political decentralisation one as administrative decentralisation and two as horizontal decentralisation - leading to a total of seven cases as one English case (planning) turned out to be a political decentralisation and administrative deconcentration at the same time - depending on the level scrutinised. In each country one person- or community-centered policy field (social help policy/RMI [FRA], integration services [GER], schools [ENG]) and one 'technical' or regulatory field (environment and trade control [GER], town and spatial planning [FRA, ENG]) were analysed. Each of the seven case-studies consist of two to four observations in local communities, drawing on secondary analysis and interviews with experts inside and outside the local authorities. This way a total of 15 observations with a total of 80 interviews were realised between 2007 and 2009. The data and an extensive analysis of the experts' judgements not always allowed for a quantitative test of the hypotheses derived from decentralisation strategies, but allowed for a rather robust estimation of the trends observed in all dimensions. To facilitate cross-strategy comparison, the encountered effects of the three decentralisation strategies are confronted in each of the six performance dimensions. The first and most prominent strategy political decentralisation is observed in the two French, the German integration services and the district-level of English town and spatial planning. Administrative decentralisation is presented second, scrutinising the German case of environmental and trade control. The third strategy compared is horizontal decentralisation applied in the field of English schools and on the regional-level of the English spatial planning administration.

\section{Empirical findings}

The findings presented in the following paragraphs are very condensed results of the extensive comparative case-studies, which can be found elsewhere (Kuhlmann et al., 2011). Due to a lack of space not all facts supporting our judgements can be presented in detail here, but will be made accessible on demand by the authors. 


\subsection{Democratic control of decision-making and accountability}

Political decentralisation is seen as the 'ideal type' of decentralisation, allowing local authorities to design and to execute policies most independently. The four cases revealed remarkably diverging developments on all of the six performance dimensions (see Table 2) after decentralisation kicked in. This is equally true for our first dimension, democratic control of decision-making and accountability.

In the two French cases of political decentralisation, the devolution of the social help policy (RMI) and the town and spatial planning administration, rather similar developments could be observed. Local democratic control and accountability formally rose, as 'classic' institutions of local democratic representation were assigned new tasks. Furthermore, with the takeover of

Table 2. Performance effects in comparison

\begin{tabular}{|c|c|c|c|c|c|c|c|c|}
\hline \multirow{3}{*}{$\begin{array}{l}\text { Performance } \\
\text { dimensions } \\
\text { Country/case } \\
\text { Policy type } \\
\end{array}$} & \multirow[b]{3}{*}{ Indicators } & \multicolumn{4}{|c|}{$\begin{array}{c}\text { Political } \\
\text { decentralisation }\end{array}$} & \multirow{3}{*}{$\begin{array}{l}\text { Adm. } \\
\text { Dec. } \\
\text { D2 } \\
\text { TP }\end{array}$} & \multicolumn{2}{|c|}{ Deconcentration } \\
\hline & & F1 & $\mathrm{F} 2$ & D1 & E1 & & E1 & $\mathrm{E} 2$ \\
\hline & & SP & $\mathrm{TP}$ & SP & TP & & TP & SP \\
\hline \multirow[t]{5}{*}{$\begin{array}{l}\text { Democratic } \\
\text { control and } \\
\text { accountability }\end{array}$} & $\begin{array}{l}\text { Formal gain in } \\
\text { political } \\
\text { competences }\end{array}$ & + & + & + & + & 0 & & \\
\hline & $\begin{array}{l}\text { Factual gain in } \\
\text { political leeway }\end{array}$ & + & + & 0 & 0 & + & & \\
\hline & $\begin{array}{l}\text { Inclusion of } \\
\text { organised } \\
\text { interests }\end{array}$ & + & + & + & + & + & 0 & + \\
\hline & Inclusion of citizens & 0 & 0 & + & + & 0 & 0 & + \\
\hline & Transparency & 0 & 0 & 0 & 0 & & & + \\
\hline \multirow[t]{3}{*}{$\begin{array}{l}\text { Horizontal } \\
\text { coordination }\end{array}$} & $\begin{array}{l}\text { Coordination } \\
\text { requirements }\end{array}$ & + & + & + & + & 0 & & \\
\hline & Conflict level & + & + & +1 & + & & 0 & \\
\hline & Constructiveness & 0 & & + & + & 0 & & \\
\hline \multirow[t]{3}{*}{$\begin{array}{l}\text { Vertical } \\
\text { coordination }\end{array}$} & $\begin{array}{l}\text { Coordination } \\
\text { requirements }\end{array}$ & & + & 0 & & & & \\
\hline & Conflict intensity & & + & & 0 & 0 & & \\
\hline & Constructiveness & + & & & & 0 & & \\
\hline \multirow[t]{3}{*}{ Efficiency } & Savings & & 0 & & + & + & & 0 \\
\hline & Input output ratio & 0 & 0 & + & + & & + & 0 \\
\hline & $\begin{array}{l}\text { Economies of scale } \\
\text { Economies of scope }\end{array}$ & 0 & 0 & + & & 0 & + & \\
\hline \multirow[t]{4}{*}{ Effectiveness } & Legal quality & + & 0 & 0 & 0 & & 0 & 0 \\
\hline & Professional quality & + & 0 & +1 & +1 & & + & 0 \\
\hline & Customer orientation & + & + & + & + & & + & + \\
\hline & Availability & + & + & + & + & 0 & & + \\
\hline Equity & Inter local equality & & 0 & & & & & \\
\hline
\end{tabular}

Note: $(+)$ increase; $(\quad)$ decline; $(+/ \quad)$ increase and decline were reported in the observations within one reform venture; $(0)$ no change. 
political or financial responsibility, the decision-makers' interest in 'policy success' - e.g. high rates of (re-)integration of beneficiaries and low public spending in RMI - increased. This urged politicians to acknowledge the beneficiaries of the RMI as voters and 'customers', and bureaucrats to integrate relevant public and private interests into the RMI policy planning. Yet, as interviews revealed, only in some cases the latter were called to participate effectively. On the one side, local councils turned to gatekeepers for the (non-)introduction of further policy-related processes or structures of participation for citizens and stakeholders (Department 1, Director of Anti-Social Exclusion Service; Department 2, Head of Social Integration Service). On the other side, in bigger cities citizens' representation rose by the now mandatory but not policy-related introduction of councils and public assemblies on urban quarter level. Smaller entities however mostly still stick to the traditional local presidential decision-making routines (Mabileau, 1996; Hoffmann-Martinot, 2007: 70). All in all, the formal strengthening of local representative democracy was only in some cases followed by an increase in participatory democracy and at the same time it often led to only sparse gains in transparency and a strengthening of the local or departmental executive (the mayor or president of the general council) (Thoenig, 2005: 695f.; Kuhlmann, 2009a: 108).

In Baden-Württemberg, Germany, the political decentralisation of the integration services revealed mixed effects concerning democratic control and accountability. First of all, only the mayors of the nine biggest cities, not the remaining 35 chief administrative officers of the counties, are elected directly. Besides somewhat weaker democratic legitimisation, these actors react differently to popular pressure. They bear primarily the interests of particular municipalities, not the policies' impact on individuals in mind. Furthermore, integration services deal with individual claims laid down in specified legislation and hence do not pose a stage for 'big politics' especially as most politicians fear to pick a quarrel with the powerful nonprofit organisations dominating the market. Political discretion is hence mostly limited to passing the fiscal pressure onto bureaucracy. Disabled citizens' opportunity to articulate their interests has reportedly increased, as decision-makers multiplied in numbers and moved closer with decentralisation (Charity 1, North County, South City). Nevertheless, formal accommodation of concerned persons in local advisory bodies and the transparency of decision-making processes is low, as professional structures still monopolise representation in most constituencies. Obviously the nonprofit organisations profit the most from the political decentralisation, outplaying the local administration in politics with the promise of (or threat of withdrawing) investments, jobs and public opinion leadership.

In England, certain aspects of the new local development frameworks $(L D F)$ for the districts are defined as political decentralisation as they unify the formerly two-tier local planning administration in one responsible political body on the lower district level. As a result, a strengthening of 
democratic accountability can be observed, as the leeway of the district councils has broadened where the LDFs are implemented. This concerns as well our own planning affairs as well as coordination and bargaining capabilities with verging territorial bodies. Nevertheless, in case of conflict with the regional spatial strategies, central government can restrict local discretion by direct intervention.

Summing up, political decentralisation misses out on the high expectations concerning democratic control and accountability. The comparison will show how the model is doing in relation to administrative and horizontal decentralisation.

Administrative decentralisation is generally seen as an 'inferior' type of decentralisation, as competences are only partly handed down to the local level and state administration maintains the right of supervision and control. Hence, no significant leeway for decision-making and democratic control should be expected following the delegation of pollution and trade control in Baden-Württemberg. However, empirical observation revealed that 'old boys and girls' networks among the local notability succeed in most constituencies to influence even smallish individual proceedings - despite high bureaucratic professionalism, formally bound decisions and hierarchical supervision. This reveals the permanent conflict between regulative duties and the facilitation of business development on the local level. Even with substantive arguments on their side, specialists are asked to 'facilitate' processes, cut back controls and 'rethink' obligations in pollution and trade control issues. 'Democratic control' hence proved to be much stronger in administrative decentralisation than in the cases of political decentralisation presented before - even it became rephrased in a rather questionable way.

In the English cases of horizontal decentralisation the assessment remains ambivalent. In the field of schools, on the one hand an enforcement of democratic self-government and participation of the persons involved (esp. parents) can be observed (cf. Pollitt et al., 1998): with schools becoming more autonomous, school boards, consisting of parents and representatives and local enterprises, gain stronger influence. An increase in parental choice and nationwide transparent benchmarking between schools (league tables etc.), can be considered a sign of a strengthened 'consumer democracy'. On the other hand, a clear weakening of representative democratic control and accountability can be seen in the neglect of democratic legitimation surpassing the individual school (County 1). The new area based 'partnerships' in the field of education and child care - which include multiple stakeholders in countywide governance arrangements - are yet not fully capable to fill the role of the local authorities (County 2). For the assessment in the field of planning in England, which is defined as horizontal decentralisation (excluding the political decentralisation on the district level described above), a weakening of democratic control and accountability must be concluded. With the abolishment of the spatial plans the counties have lost all their influence (with exception of minor responsibilities like 
waste and minerals). The new regional tier with its threefold governance (regional planning bodies, regional assemblies (and their successors) and government offices) structure shows clear deficits in transparency and democratic accountability. The effects of the obligatory citizen participation remain weak due to selectivity in participation ('usual suspects') and moderate influence on decisions.

In total, the assumption of positive effects of decentralisation on democratic control and accountability can be confirmed. Yet, no decentralisation strategy can be designated as clearly superior. Each one shows certain advantages but misses out on other aspects. Hence, despite heightened formal legitimation, political leeway and citizen participation remain low in political decentralisation as strong stakeholders still dominate decision-taking processes. In administrative decentralisation local political actors are strengthened (unrightfully) while formal legitimation and transparency stay weak. And horizontal decentralisation finally improves stakeholders' participation while missing out on other aspects of legitimisation and political accountability.

\subsection{Horizontal coordination}

The dimension of horizontal coordination is geared to measure the ability to develop comprehensive and integrated policy solutions on the local level. Here, the first of our four cases of political decentralisation - the French RMI and town and spatial planning - revealed how challenging it can prove to local-level decision-makers to manage more and more complex systems (Kuhlmann, 2009a: 109). Taking the French RMI-policy as an example, this policy encompassed a coordination-intensive case management approach already before decentralisation. Yet, with the states' retreat, the Conseil général got responsible to manage coordination with the wide range of different public and private local service providers. In one case, where coordination had traditionally been based on a 'corporatist' relationship between the guarantor of RMI-related functions and the service providers, this was seen as an excessive demand on the local bureaucracies. Yet in another, where the Conseil général chose a 'marketisation' of service production and 'economisation' of coordination, the management of complexity proved to function well. To increase inner-administrative horizontal coordination, the different Conseil généraux typically reacted either with a strategy of inner-departmental centralisation or with a strategy of a stronger inner-departmental decentralisation (IGAS, 2007). Despite all odds, the interviewees agreed that decentralisation has in sum positive effects regarding the capacity for horizontal coordination.

In the second French case, the political decentralisation of town and spatial planning, the differences between the bigger and smaller communities in their ability to successfully coordinate affairs proofed decisive. Cities above a certain size showed much elaborated coordination routines within 
and between administrations as well as between the administration and third parties. Longstanding experience in inter-local regimes seemed to facilitate this processes further (Mabileau, 1996). Curiously, private actors contracted by municipalities proved to be the most reluctant players to take part in joint efforts for inter-communal coordination. Small towns and villages without their own personal resources become trapped in a typical principalagent dilemma. This case showed the importance of context factors, as size and capabilities in economic, political and cultural aspects became obvious.

Political decentralisation of integration services in Baden-Württemberg/ Germany equally transferred complex horizontal coordination issues to the local level. After initial difficulties, this challenge was handled remarkably well and allowed the bundling of most social services on the local level for the first time. As a consequence interfaces with school authorities, public health departments or youth welfare offices were smoothed as the merits of face-to-face contact between bureaucrats and local actors took effect. Furthermore the comprehensive implementation of a case-management approach became possible. Quality increased as the case managers' knowledge of local service providers improved. As a downside, the need for horizontal coordination between the local entities increased dramatically with decentralisation (Charity 1,3,4). As counties now have to react to legal changes or newly arising professional questions on their own, they are forced to harmonise their decisions in a host of inter-municipal meeting rounds at substantial interaction costs. Despite this difficulty, decentralisation opens up new chances for integrated services at the local level.

For the political decentralisation of planning on the English district level, we can observe an improvement of horizontal coordination, especially in the field of development control, but also for other policies. Expected deficits regarding the coordination with counties' tasks could not be identified. According to the interviewees these processes are usually bilateral in nature and independent from institutional affiliation for the main part. Horizontal coordination between municipalities equally improved as it profited from the bundling of local planning tasks in one body.

In comparison to the cases presented under the header of political decentralisation, interviewees from the administratively decentralised pollution and trade control departments emphasised the importance of horizontal coordination and communication within the 44 counties' pollution and trade control administrations. Due to the exigencies of the policy field, it is considered of paramount importance to harmonise courses of action, update qualifications and make up for decentralisation-induced losses in specialisation (all). As informal networks are the basis for most of these relations, they are severely threatened with erosion over time. Low capacity counties with weak personal resources reportedly already dropped out of both formal and informal networks. At the same time, judgements about inner administrative horizontal coordination are mixed: while in some 
counties the facilitation of everyday coordination was praised, others commented, 'it doesn't matter, where the peer sits I exchange emails with' (North City). All experts stressed the potential for the further improvement of coordination processes - while expressing pessimism concerning its realisation due to inter-department struggles, entrenched routines and opposed political interests.

For the English case of horizontal decentralisation in the field of schooling the evidence shows clear deficits in horizontal coordination. Between schools, due to the diminishing planning capacity of the LEA, schools now compete for personnel and common goods like rooms, sports facilities or food provision. Between schools and local authorities similarly a weakening of coordination in crosscutting issues as youth welfare, crime prevention, planning and leisure or sports facilities is reported regularly: 'The local authority has cut us off'. As a counter move vertical coordination was strengthened through national curricula and league tables and state-led inspectorates (OFSTED), whose effects are disputed: gains in transparency go hand in hand with high administrative costs and 'gaming' (cf. Hood 2006) behaviour by individual schools. These negative findings were triggers of reforms aiming to promote better coordination with other services (integration of educational services with child care etc.). At the time of research, these reforms struggled with hindrances and different 'administrative cultures' between the now integrated services (County 2).

For the horizontal decentralisation on the regional planning level in England, we find conversed developments to the political decentralisation on the district level. Here planning processes are decoupled from other policies as the mono-functional planning bodies concentrate on planning responsibilities only. The remaining other significant task - regional economic and structural development - is assigned to other bodies, creating a certain degree of institutional rivalry. The resulting deficits are the motive of ongoing legislation.

In sum, the comparison of the three decentralisation strategies concerning their effects on horizontal coordination showed controversial results: while for cases of political decentralisation mostly positive or at least neutral developments could be observed, the administrative decentralisation in pollution and trade control created a massive need for horizontal coordination between local units, which is currently not met, while potential gains in inner-administrative coordination are hardly realised. Horizontal decentralisation in England seems to fail completely to achieve horizontal coordination requirements. Obviously coordination needs vary greatly between policy fields, their satisfaction depends on a whole array of factors, from size to culture and (micro-)political rationales. One bottom line for all cases investigated seems to be a positive relationship between 'meta'resources like knowledge, contacts/networks and time to build up routines on the one side and coordinative performance on the horizontal level on the other. 


\subsection{Vertical coordination}

The dimension of vertical coordination displays the need and ability to coordinate policy formulation and implementation between levels of government. In the first of the four political decentralisation cases, the French $R M I$, deficits in vertical coordination between the departments and the state has to be diagnosed. Problems arise out of flimsy legislation, declaring the Conseil généraux to the informal heads ('chefs de file') of the RMI-implementation, but failing to regulate the relationship between the departments and their local implementation 'partners'. Due to communal law - which does not state a formal hierarchy between the different types of local governments - all involved communalities (departments, municipalities, regions) are formally coequal in implementation. Yet, due to the traditions of (local) public function fulfilment, the involved communalities as the other non-governmental partners of the department are tied to this 'chef de file' on a contractual basis. As a consequence, departmental office holders reported regularly of coordination problems especially with their municipal partners (Department 1, Executive Officer Anti Social Exclusion Service). In the second case of political decentralisation of town and spatial planning in France the differences in capacity between big and medium-sized cities on the one side and small municipalities on the other side again arises as a major factor for understanding performance change in vertical coordination. After the transfer of functions onto the cities, vertical coordination between bigger cities and the state was reduced to the minimum of the legally obligatory coordination, e.g. with regard to information exchange in matters of civil protection. In these respects, coordination proofs to function well as the few concerned actors from both levels share a professional interest and interact on the basis of clearly and formally stated work-sharing. As smaller cities often lack the knowledge, financial and personnel resources to fulfil their acquired planning functions, coordination between the local and the state level of government here is much more intensive than with regard to bigger municipalities (Wollmann, 2008). Interesting in this respect is that consultancy by the states' decentralised planning authorities is higher valued by local decision-takers today than the services of the newly appeared private planning bureaus (Executive Officer Municipality 2/Department 2, State Planning and Construction Authority; Municipality 1, Head of Local Construction Service).

In the Baden-Württemberg/Germany case of integration services, vertical coordination is limited almost exclusively to the relation between the local entities and the communities' joint facility, the Kommunalverband Jugend und Soziales (KVJS). Disempowered and downsized, this organisation still acts as a support unit in limited ways, e.g. the professional assessment of the needs of disabled persons (North County, HoD; Charity 5). But lacking hierarchical competences and facing growing reluctance of local 
decision-makers to follow standards and routines whatsoever, the KVJS' role is marginalised more and more, leading to ever weaker vertical coordination (Charity 1, 3, 5).

Finally, the English case of local planning shows contradictory results. On the one hand the need for vertical coordination between districts and counties has been reduced to a minimum. On the other hand the vertical coordination with the regional bodies and especially the Government Offices has become more problematic - at least in cases were political differences about planning applications are occurring.

The administrative decentralisation of pollution and trade control in Baden-Württemberg/Germany increased the need for specialised knowledge dramatically. In contrast to the horizontal relations - no severe problems in vertical coordination between the counties and the state's four regional supervisory authorities, the Regierungspräsidien were reported. After sorting competences, the states administration slipped whenever possible in the role of a consultant, not of a supervising body. Despite this constructive atmosphere, the communities' needs for support cannot be met due to lacking capacities.

The English horizontal decentralisation of schools is marked by increasing vertical integration. The number of contacts and interfaces between representatives of the state and the individual schools as well as local authorities has increased. In both cases the authoritative style of central governments' intervention has reinforced and manifests itself especially in the rigid system of inspections and performance management - even strengthened under New Labour. Another facet of central government's interference is the use of application-based programmes for special needs, which tend to fence local leeway.

In the field of planning a more clear-cut differentiation of tasks in the vertical dimension took place. In spite of its increased autonomy, the district level remains subject to a number of vertical interventions. On the one hand the often reported direct discretionary interventions of the secretary of state (Wollmann, 2008) have been reduced. On the other hand the development of local development frameworks is supervised by the Government Offices and is subject to a final examination by the states' planning inspectorate. Conflicts in intergovernmental relations develop especially in the case of discrepancies between local and regional planning, which are often stiffened by different political preferences.

Summing up the empirical observations, decentralisation led to a rise in the need for vertical coordination, which has has not been met. While in some cases of political decentralisation quarrels for competencies and lacking hierarchies are to blame, the English cases of horizontal decentralisation show overly regulated top-down steering. Between these poles, political decentralisation in the French town and spatial planning and administrative decentralisation in pollution and trade control appear as 
remarkable exceptions; here, well balanced and structured relations could be observed.

\subsection{Efficiency}

The efficiency dimension measures changes in cost-efficiency of serviceproduction after decentralisation. Political decentralisation of the French $R M I$ entailed a loss in cost efficiency as a series of financial risks realised after the transfer of tasks onto the departments. On the one hand, departments then had to carry the total risk of variations in the number of beneficiaries and of the changes in revenues from wrongfully paid transfers, by 2008 some 120 million Euros (ODAS, 2009: 9; Clerc, 2009). To control these uncertainties, the departments started to enforce stricter checks on individual beneficiaries and mostly managed to contain total spending. On the other hand, increases in costs resulted from the departments' eagerness to uphold high service quality and the consecutive investment in additional personnel and the adjustment of internal management processes and technical support (Kuhlmann, 2009a; Kuhlmann, 2009b). In sum, empirical observations suggest a short-term increase of costs (Department 1, Executive Officer Anti-Social Exclusion Service; Department 2, Head of Social Integration Service). The same is not true regarding the second case of political decentralisation in France, the town and spatial planning policy. Here marked efficiency effects cannot be assessed either on the side of bigger cities or on the side of the small municipalities. In the early days after the transfer of tasks big cities had to bear transaction costs due to an investment in their local administrative and personnel capacities, yet more than 20 years after the transfer these investments nowadays pay-off. Smaller communities with less than 10,000 inhabitants on the other side still today profit from the states' gratuitous provision of planning-related administrative services (Wollmann, 2008: 190).

In the Baden-Württemberg/Germany case of political decentralisation of the integration services, cost-efficiency decreased severely with the fragmentation of tasks, the loss of centrally provided back-office services and the investments to build up case-management capacities. Due to an uneven distribution of qualified personnel between them, counties had to face rather differing starting conditions concerning resources (cf. Ebinger \& Bogumil 2008), but all share the same pressure to keep an eye on costs. With some delay nearly all local decision-makers accepted the investment in casemanagement capabilities and the provision of tailor-made solutions to disabled citizens as the only way to slow down the explosion of costs written at the wall (all). Better coordination amongst the local services already leads to efficiency gains. In sum, decentralisation made meaningful investments in the field of integration services politically feasible at all. This could in turn lead to a substantial reduction of costs and a leap forward in service quality in the future. 
In the case of English planning the districts' departments have expanded their staffs, which lead to higher costs at least in the period of transition to the new system. In 'daily work' we can assume some potential for efficiency gains due to reduced coordination processes between planning and development control.

The case of pollution and trade control in Baden-Württemberg offers a typical example for a politically motivated administrative decentralisation. Hence the municipalities - eager to absorb additional competences - had to accept a 20 per cent cut in the states' cost coverage. Given the fact that the number of personnel available for a reallocation to the county level was insufficient at the outset, the necessary savings were often made in one fell swoop right with the transfer of functions. As some municipalities not only want to cover costs but to make money out of the decentralisation, some staff are down 30 per cent in the few years since decentralisation (South City; North County). While sizeable departments took this beating fairly well, many smaller counties are confronted with persistent structural problems concerning all resources. To go by the general estimation of interviewees, competence deficits and resulting follow-up costs for public authorities, businesses and citizens exceed by far the immediate savings accompanying decentralisation.

In the field of English schools, to the present day, efficiency gains remain disputable. Most gains can be ascribed not to administrative changes, but to new flexible budgets introduced in both LEA and GM schools (cf. Levacic, 1994). Indeed, there are indications of higher administrative costs in GM schools through internalisation of administrative functions (e.g. personnel, building maintenance) and a de-professionalisation of administrative functions through self-government. As a headmaster told us, due to several reform movements he wasn't able to give clear evidence on efficiency gains (County 1, Headmaster Secondary School).

In the field of planning only a preliminary assessment of efficiency effects is possible. With the abolishment of spatial plans at county level, staffs were reduced considerably. The new regional planning bodies are staffed slimmer, suggesting efficiency gains on the first glance. However, more staff is bound at the states' government offices and the planning inspectorate, so that overall efficiency gains are arguable.

In a nutshell, the comparison of decentralisation strategies'. effects on efficiency bears unclear results. Nevertheless, a policy related effect can be observed: rather technical tasks do not deliver gains in any case, while in both cases of integration services positive effects are to be expected on the long run.

\subsection{Effectiveness}

Concerning effectiveness, the legal and professional quality as well as the administration's responsiveness in the execution of tasks has been 
scrutinised. In the French $R M I$ case, decentralisation and policy reform coincided, making a separation of effects difficult. Many departments invested in professionalising their staff to achieve the newly set standards. Yet the 'qualification offensive' can yield its fruits only with delay as local social workers have to acquire new management skills and acquaint themselves with new policy instruments (Department 1, Executive Officer of Local Social Centre). Additionally, the new orientation of the RMI-policy in the direction of an active employment policy entailed the necessity to reshape already existing and often well-functioning partnerships, which contributed to at least short-term losses in effectiveness regarding professional quality (Department 1, Executive Officer Anti-Social Exclusion Service; cf. IGAS, 2007). All in all though, effectiveness did not decrease subsequent to decentralisation but due to the duality of decentralisation and RMI-policy reforms. Improvements in the future thus seem possible. In the case of the political decentralisation of town and spatial planning policy functions the development was similar. Here, the professionalisation of local administrations of big and medium-sized cities (cf. Kuhlmann, 2008) in the medium run contributed to maintaining a high professional standard in the aftermath of decentralisation (Municipality 2, Head of Local Construction Service). As small cities on the other hand could and still can profit from the state agencies' professional and administrative support, decentralisation did not go hand in hand with losses in professional or in legal quality (Municipality/Department 1, Executive Officer in the States' Planning and Construction Authority).

Looking at the effectiveness dimension in the field of integration services in Baden-Württemberg, the importance of resource availability and political support became obvious. Favourably institutionalised entities could establish comprehensive case-management capacities and tighten in-house and external relations with all actors involved in the support of disabled citizens. Closer multilateral cooperation improved controlling and helped to refine the range of services offered by third-party providers. Thus the use of ambulant and low-threshold services could be expanded and overall service quality improved. In other, less favourably institutionalised cases, experts and stakeholders report of high pressures exerted on case managers to cut costs by any means (Charity 2, 3, 4). Independent of available administrative capacities, the quality of services offered seems mostly determined by the disabled persons - or their families' - possibility to voice and enforce their needs.

The effectiveness of the new English planning system can be divided regarding procedural and substantive objectives. Procedurally we can observe two distinct developments. Due to simplified coordination between planning and development control we can assume higher achievement of objectives on the district level. However, an inherent conflict lies in the reconcilement of local and regional interests. This hindrance to an effective planning organisation leads to very low adoption rates of 
local plans so far. Regarding the substantial achievement of objectives, better result are reported for the level of districts that gained autonomy. However, the potential conflicts with regional planning authorities can lead to deferred planning processes due to the strengthened influence of the state level.

For the administrative decentralisation of pollution and trade control a more unambiguous conclusion has to be drawn. Considerable deficits resulted from the loss of specialised knowledge. Instead of around 50-70 experts in the former state-run pollution and trade control agencies, the 44 communal entities employ only five to $15 \mathrm{staff}$ each. As a consequence, a 'despecialisation' became apparent, even though service quality heavily depends on county size. Case-managers are now responsible for around 10 industrial branches in smaller counties, an assignment that is considered beyond reason. Interviewees reported of a rise in handling times, decreased service quality and a loss of external reputation.

Regarding the English horizontal decentralisation case of schools no clear standardisation of results has taken place, which clearly runs counter to the aims of an increase in centralised control of school performance. Some improvements in problem-driven allocation of the schools' resources were reported. However, differences between schools can be traced back to the social background of the area rather than to school governance (County 1, Head of Services Area Education Office) and the more autonomous schools miss out regarding the integration of education and social work. The 'partnership' approach wasn't able yet to cope with these deficiencies. In sum, there is little evidence so far for an increase in effectiveness that could be attributed to the deconcentration in the education sector. The effectiveness of the 'horizontal' decentralised level of regional planning is hindered by political and juridical hindrances especially from the local level, which block the adoption and effective implementation of the regional spatial strategies.

Comparing the decentralisation strategies, we find some clustering of positive effects of political decentralisation on local government performance while the results regarding the other strategies are rather negative or mixed. Hence, technical tasks do not deliver directly positive effects either. Summing up, again context factors such as policy field, time elapsed since the reform and size of the constituencies seem to explain more of the observed variance than the decentralisation strategies themselves.

\subsection{Heterogeneity of service production between local units}

The dimension heterogeneity of service production displays the ability of the administrative setting to produce a homogenous service level throughout the country. The political decentralisation of the $R M I$ in France clearly contributed to an increase in the already existing trans-territorial heterogeneity of social public service production (cf. Mission parlementaire, 
2009: 13). Departments under budgetary constraint were reportedly not able to afford an expansion of the range of integration services to the 'RMIst' (Department 1, Director of Anti-Social Exclusion Service). In the second French case of town and spatial planning, adequate local differentiation could be considered positive as it is a sign of responsiveness to the local communities' needs and challenges regarding planning. Here, little such development was observed: an overall defective institutionalisation of intercommunal corporations and the hesitancy of (smaller) communities to take responsibility slowed down this process.

In Baden-Württemberg/Germany, the different starting conditions and management philosophies in integration services led to very different approaches in institutionalisation, instruments and the dealing with claims of potentially entitled persons. While some executives installed integrated social affairs departments or invested in building up capacities for case management, others did not. And whereas the majority of counties are anxious to find a commonly acceptable balance between a desirable service level and rigid cost-cutting, a few exclusively aim to undercut costs. To somehow harmonise execution a multitude of coordinative meetings and commonly edited guidelines is necessary (North County, Head of Department). Obviously, as strategies and instruments get harmonised, the cultural differences between counties in the dealings with disabled citizens' needs remain.

With the strengthened role of the state in the new English planning system, along with the guiding role of the government offices and the Planning Inspectorate, with the authority for approving of local plans, there is a certain homogenisation of planning on the procedural level. However, in the recent implementation process this provokes - partly politically motivated resistance by certain councils, which leads to big heterogeneity in the adoption of local plans.

The administrative decentralisation of pollution and trade control in Baden-Württemberg led to substantial heterogeneity. Unequal deployment of specialists, participation in trainings and meetings as well as access to informal networks further increased discrepancies.

Subsequent to horizontal decentralisation, the heterogeneity between schools as well as between different local authorities has increased in the English cases. Some commentators see this as an intended consequence of the horizontal decentralisation approach. Hence, despite growing discrepancies, there is little evidence of improved services through competition. On the contrary, this heterogeneity increases pre-existing advantages and disadvantages of single schools in relation to the social background of the pupils, building maintenance and the recruitment of teachers. In both counties these inequities occurred and are reported to be a major problem for building up community-wide strategies for the improvement of educational policies. In the area of the English planning, the leading role of the secretary of state and the standardising of the government offices are 
convergent developments observable. Variance in substantial planning applications is due to different national planning targets, which plead for affordable houses in the south, and the coping with structural change in the north.

Summing up, similar results can be reported for all decentralisation strategies: in all cases heterogeneity increased and financial resources as well as political will were the main drivers of this dynamic.

\section{Conclusion}

The aim of this paper was to study the role of differing decentralisation strategies. In this respect, an analytical framework that had been developed in a comprehensive research project as an analytical tool to evaluate the impact of national decentralisation policies on local government performance was utilised. Guided by this framework six reform ventures in France, Germany and England were scrutinised. A total of 15 in-depth observations were carried out in the course of the project, applying a comprehensive theoretical framework based on six performance dimensions and a broad set of indicators. In this article, the empirical results of the research project were presented in order to deliver an empirical comparative insight into the performance effects of decentralisation reforms.

Direct relations between decentralisation strategies and performance effects on certain dimensions are not warranted. To the contrary, it became apparent that some classic hypotheses concerning the effects of certain decentralisation strategies have to be questioned. As reported, political decentralisation increased democratic control and accountability often only formally, mostly favouring special interest groups and the local executive, not citizens. Political leeway surprisingly increased most in administrative decentralisation - in a rather questionable way. The English horizontal decentralisation strategy proofed to combine the disadvantages of central and decentralised responsibility, leaving the fragmented administrations squeezed between a host of local stakeholders and rigid central surveillance. It became obvious that the explanatory power of decentralisation strategies stays limited. Apparently a classic set of context variables seems to better account for most effects: characteristics of the policy field, political goals of decision-makers and the time passed since the reform intervene strongly. More technical tasks require bigger constituencies to attain the necessary critical size for an inter-sectoral division of labour and the realisation of economies of scale. Social policy tasks can (but do not need to) profit most from tight horizontal integration between the fragmented services and thus can reach new levels of integrated service quality. Political interests can modify all institutional settings in the most positive and negative ways. And any reform bears substantial financial and functional transformation costs leading to a much delayed break even. 
As a consequence it can be concluded that decentralisation as an institutional policy makes a difference, but that the direction of change should not be supposed to being derived first and foremost from the institutional strategy chosen. An integrative view including institutional and policy reforms, functional necessities of the tasks and political interests has to be applied.

\section{Notes}

1. The case studies were conducted in the comparative research project 'European Local Systems under Change: Institutional Decentralisation and its Effects funded by the Deutsche Forschungsgemeinschaft (DFG)'. The research is jointly headed by Jorg Bogumil and Sabine Kuhlmann and carried out by the authors of this contribution. A comprehensive summary including outline and results of the research project can be found in Kuhlmann et al., 2011 and Reiter et al., 2010. For a concise outline of the research project cf. Ebinger et al., 2010. Further information at http://www.sowi.rub.de/regionalpolitik/forschung/wandel.html.de and http://www.hfv speyer.de/Kuhlmann/Forschung/WandelLokal.htm.

2. The RMI (Revenu minimum d'insertion) has meanwhile been replaced by the newly created RSA (Revenu de solidarité active) in June 2009.

\section{References}

Ahmad, E. \& Brosio, G. (2008) Handbook of Fiscal Federalism (Cheltenham: Edward Elgar).

Bauer, M. W., Bogumil, J., Knill, Chr., Ebinger, F., Krapf, S. \& Reißig, K. (2007) Modernisierung der Umweltverwaltung. Reformstrategien und Effekte in den Bundesländern (Berlin: Ed. Sigma).

Benz, A. (2002) Die territoriale dimension von verwaltung, in: K. Konig (Ed.) Deutsche Verwaltung an der Wende zum 21. Jahrhundert, pp. 207228 (Baden Baden: Nomos).

Bogumil, J. \& Ebinger, F. (2008) Verwaltungspolitik in den bundeslandern vom stiefkind zum darling der politik, in: A. Hildebrandt \& F. Wolf (Eds) Die Politik der Bundesländer. Politikfelder und Institutionenpolitik, pp. 275288 (Wiesbaden: VS).

Bogumil, J., Grohs, S., Ohm, Anna K. \& Kuhlmann, S. (2007) Zehn Jahre Neues Steuerungsmodell. Eine Bilanz Kommunaler Verwaltungsmodernisierung (Berlin: Ed. Sigma).

Bogumil, J. \& Kuhlmann, S. (2006) Wirkungen lokaler verwaltungsreformen: Moglichkeiten und probleme der performanzevaluation, in: W. Jann, M. Rober \& H. Wollman (Ed.) Public Management Grundlagen, Wirkungen, Kritik, pp. 349370 (Berlin: Ed. Sigma).

Bogumil, J., Reichard, Chr. \& Siebart, P. (2004) Gutachten zur Verwaltungsstrukturreform in $N R W$ (Ibbenburen: IVD).

Boyne, G. A., Farrell, C., Law, J., Powell, M. \& Walker, R. M. (2003) Evaluating Public Management Reforms. Principles and Practice (Buckingham: Open University Press).

Clerc, D. (2009) Décryptage de la loi du 1er décembre 2008 (2e partie): Les mesures relatives au revenu de solidarité active, La Lettre de l'Insertion, 9.

Connolly, T., Conlon, E. J., Deutsch \& Stuart, J. (1980) Organizational effectiveness: a multiple constituency approach. Academy of Management Review, 5(2), pp. 211217.

Deffigier, C. (2007) Intercommunalité et Territorialisation de l'action publique en Europe. Revue Française d'Administration Publique, 121 122(1 2), pp. 7998.

Denters, B. \& Rose, L. (Eds) (2005) Comparing Local Governance: Trends and Developments (New York: Palgrave).

Ebinger, F. \& Bogumil, J. (2008) Grenzen der subsidiaritat verwaltungsreform und kommunalisierung in den landern, in: H. Heinelt \& A. Vetter (Eds) Lokale Politikforschung Heute, pp. 165196 (Wiesbaden: VS). 
Ebinger, F., Grohs, S., Reiter, R. \& Kuhlmann, S. (2010) Institutional decentralisation policies as multi level governance strategies evaluating the impacts of decentralisation in Western Europe, in: M. Holzer, A. Massey, E. Ongaro \& E. Wayenberg (Eds) Governance and Intergovernmental Relations in the European Union and the United States, pp. 180194 (Cheltenham: Edward Elgar).

Enticott, G. (2004) Multiple voices of modernization: some methodological implications, Public Administration, 82(3), pp. 743756.

George, A. \& Bennett, A. (2005) Case Studies and Theory Development in the Social Sciences (Cambridge, Mas.: MIT Press).

Hoffmann Martinot, V. (2007) Le Gouvernement des Villes. Une Comparaison Internationale (Paris: L'Harmattan).

Hood, Ch. (2006) Gaming in targetworld: the targets approach to managing British public services, Public Administration Review, 66(4), pp. 515521.

IGAS (Inspection générale des affaires sociales) (2007) Rapport sur la Gestion du Revenue Minimum d'Insertion (RMI). Présenté par J. F. Chevallereaux, M. Laroque, M. Moleux \& I. Rougier. Rapport RM2007 165P, Novembre 2007. Available at: http://lesrapports. ladocumentationfrancaise.fr/BRP/074000760/0000.pdf (accessed 6 October 2009).

Kuhlmann, S. (2006) Local authorities between the state and the market: an international comparison of local government systems and reforms, German Journal of Urban Studies, 45(2), pp. 546.

Kuhlmann, S. (2008) Dezentralisierung in Frankreich: Ende der unteilbaren republik? Der Moderne Staat dms, 1(1), pp. 201220.

Kuhlmann, S. (2009a) Politik und Verwaltungsreform in Kontinentaleuropa: Subnationaler Institutionenwandel im Deutsch Französischen Vergleich (Baden Baden: Nomos).

Kuhlmann, S. (2009b) Frankreich: Wandlungen des jakobinischen staates "faire mieux avec moins"?, in: Europaisches zentrum fur foderalismus forschung Tubingen (Ed.) Jahrbuch des Föderalismus 2009, pp. 263274 (Baden Baden: Nomos).

Kuhlmann, S., Bogumil, J. \& Grohs, S. (2008) Evaluating administrative modernization in German local governments: success or failure of the 'New Steering Model'?, Public Administration Review, 68(5), pp. 851863.

Kuhlmann, S., Bogumil, J., Ebinger, F., Grohs, S. \& Reiter, R. (2011) Dezentralisierung des Staates in Europa: Auswirkungen auf die Kommunale Aufgabenerfüllung in Deutschland, Frankreich und Großbritannien (Wiesbaden: VS).

Levacic, R. (1994) Evaluating the performance of Quasi markets in education, in: W. Bartlett, C. Propper, D. Wilson \& J. LeGrand (Eds.), Quasi Markets in the Welfare State (Bristol: Saus Publications).

Mabileau, A. (1996) Kommunalpolitik und Verwaltung in Frankreich. Das "Lokale System" Frankreichs (Basel: Birkhauser).

Mission parlementaire sur les droits connexes dans le cadre de la généralisation du RSA (2009) Rapport de Madame S. Desmarescaux, Sénateur. C. Hesse, Membre de l'inspection générale des affaires sociales, Mai 2009. Available at: http://lesrapports.ladocumentation francaise.fr/BRP/094000221/0000.pdf (accessed 8 October 2009).

Munck, G. (2004) Tools for qualitative research, in: H. E. Brady \& D. Collier (Eds) Rethinking Social Inquiry. Diverse Toools, Shared Standards, pp. 105122 (Lanham: Rowman and Littlefield).

ODAS (Observatoire national de l'action sociale décentralisée) (2009) Dépenses départemen tales d'action sociale en 2008: la fin d'un cycle. La Lettre de l'Odas.

Peters, G. (2008) The Napoleonic tradition, International Journal of Public Sector Management, 21(2), pp. 118132.

Pollitt, Chr. (2005) Decentralisation, in: E. Ferlie, L. E. Lynn \& Chr. Pollitt (Eds) The Oxford Handbook of Public Management, pp. 371397 (Oxford: OUP).

Pollitt, Chr. \& Bouckaert, G. (2004) Public Management Reform: a Comparative Analysis, 2nd ed. (Oxford: OUP). 
Pollitt, Chr., Birchall, J. \& Putman, K. (1998) Decentralising Public Service Management (Houndsmills: Macmillan).

Reiter, R., Grohs, S., Ebinger, F., Kuhlmann, S. \& Bogumil, J. (2010) Impacts of decentralization. The French experience in a comparative perspective, French Politics, 8(2), pp. 166189.

Skelcher, C. (1998) The Appointed State: Quasi Governmental Organizations and Democracy (Buckingham: Open University Press).

Thoenig, J. Cl. (2005) Territorial administration and political control: decentralisation in France, Public Administration, 83(3), pp. 685708.

Wagener, F. (1976) Typen der verselbstandigten erfullung offentlicher aufgaben, in: F. Wagener (Ed.) Verselbständigung von Verwaltungsträgern, pp. 3151 (Bonn: Deutsche Sektion).

Wilson, D. \& Game, Chr. (2006) Local Government in the United Kingdom, 4th ed. (Houndsmills: Palgrave).

Wollmann, H. (1997) Echte kommunalisierung der verwaltungsaufgaben: Innovatives leitbild fur umfassende funktionalreform? Landes und Kommunalverwaltung ( $L K V)$, 7(4), pp. 105 144.

Wollmann, H. (2004) Local government reforms in Great Britain, Sweden, Germany and France: between multi function and single purpose organisations, Local Government Studies, 20(4), pp. 639665.

Wollmann, H. (2008) Reformen in Kommunalpolitik und Verwaltung. England, Schweden, Frankreich und Deutschland im Vergleich (Wiesbaden: VS).

Wollmann, H. \& Bouckaert, G. (2006) State organisation in France and Germany between territoriality and functionality, in: V. Hoffmann Martinot \& H. Wollmann (Eds) State and Local Government Reforms in France and Germany. Divergence and Convergence, pp. 1137 (Wiesbaden: VS). 